\title{
BROWNIES FROM MANGROVE FRUIT FLOUR: THE USE OF VARIATION OF FLOURS AS AN ALTERNATIVE TO HIGH FOOD NUTRITION
}

\author{
Sumartini $^{1 *}$, Kurnia Sada Harahap ${ }^{1}$, Apri Mujiyanti ${ }^{1}$
}

${ }^{1}$ Processing Marine Products, Polytechnic of Fisheries and Marine, Dumai, Riau Province, Indonesia

*) Corresponding Author: sumartini@politeknikkpdumai.ac.id/tinny.sumardi@gmail.com

\begin{abstract}
Brownies is a popular high-calorie snack. In this studied, brownies were processed from several types of flour, namely pedada fruit (Sonneratia caseolaris) flour, api-api (Avicennia officinalis) flour, red bean flour, and modified cassava flour with nutritional value and health benefits compared to the commercial ones (from wheat flour). The purpose of this studied was to determine the used of a variety of superior flours as raw material for making brownies in terms of nutritional value and leveled of preference. The experimental design used a completely randomized design (CRD) with test parameters including the leveled of preference, caloric value, fiber, and proximate composition. The results of the studied were tested for variance using spss version 22 software with a $95 \%$ confidence interval. The results showed that the best results were brownies made from pedada fruit flour because they had higher fiber and lowered calories with test scores for calorie content, crude fiber, air content, fat content, protein content, ash content, carbohydrate content respectively. $401.87 \mathrm{kcal}$ each; $16.49 \%$; $18.32 \%$; 21. $7 \%$; 4. 03\%; $1.44 \%$; and 54 . $64 \%$.
\end{abstract}

Keywords: Mangrove Fruit, Sonneratia, Avicennia, Flour, Brownies

\section{INTRODUCTION}

Brownies is very popular cake because it tastes sweet and delicious. According to Astawan (2009), brownies is a kind of blackish-brown cake with a slightly hard texture because the development of gluten is not required in the process of making brownies. Brownies are a kind of solid textured chocolate cake made from wheat flour, eggs, fat, granulated sugar and chocolate as the basic ingredients for making cakes (Anam and Sanjaya 2018). With a mixture of those ingredients, brownies is packed with high calorie value but low in food fiber. The high calorie value and sugar content of brownies is the main concern from brownies consumers. Consumption of high calorie and sugar-rich food could result in in an increased risk of metabolic syndrome such as diabetes mellitus and coronary heart disease. Also, despite of the good taste, the nutritional content of brownies is still considered

to be lacking. Therefore, it is interesting to look for alternative raw materials to substitute wheat flour with local ingredients that are superior in terms of nutrition, such as mangrove, modified cassava, and red bean flour. Those flours have different nutritional content and advantages.

There are so many alternative raw materials that used as ingredient subtitute in making brownies. Previous studies on substituting brownies ingredients used black bean flour (Uruakpa \& Fleischer, 2016), cassava with taro and tomato (Khamidah and Natural, 2011), potato starch (Ligarnasari et al., 2018), seaweed (Purwonegoro \& Sulistiyati, 2019), mangrove fruit flour as Wikao maombo cake (Wahyuni et al., 2018), black oncom (fermented tofu by-products), and sorghum (Reni and Budi, 2018). There are still many potential food source alternatives having high carbohydrate content, but are rarely utilized. According to Pentury (2016) Bruguierra gymnorrhiza andAvicennia marina mangrove fruit species have high carbohydrate content. The carbohydrate content of the mangrove species (Bruguierra gymnorrhiza) was $78.85 \pm 0.030$, Pedada fruit (Sonneratia alba) was $68.41 \pm 0.22$ and Rhyzophora was $75.740 \pm 0,46$ (Talib et al., 2018). Red bean also contains good nutritional content as an alternative ingredient for making brownies because it is rich in fiber and protein.

The several previous studies used several raw materials such as red bean flour, modified cassava flour, and wheat flour. The choice of raw materials is generally based on low prices and the fortification of certain ingredients in the raw materials, such as the nutrient-rich red bean flour In addition, red beans are a type of food and agricultural products available in large quantities in Indonesia. Its nutritional content is good for the body, so it needs to be developed to diversify functional foods. The nutritional value contained in fresh kidney beans is $171 \mathrm{kcal}$ energy, 11 $\mathrm{g}$ protein, $2.2 \mathrm{~g}$ fat, and $28 \mathrm{~g}$ carbohydrates, $293 \mathrm{~g}$ calcium, $134 \mathrm{mg}$ phosphorus, $3.7 \mathrm{mg} \mathrm{Fe}, 0.2 \mathrm{mg}$ vitamin $\mathrm{B} 1$, water 57 and edible weight (BDD) $100 \%$ energy of medium dry red beans $314 \mathrm{kcal}$, protein $22.1 \mathrm{~g}$, fat 1.1 and carbohydrate $56.2 \mathrm{~g}$, calcium $502 \mathrm{~g}$, phosphorus $429 \mathrm{mg}$, Fe $10.3 \mathrm{mg}$, vitamin A 0 , vitamin B1 $0.4 \mathrm{mg}$, water 18 and BDD 97\%. (MOH RI, 2005).

Another ingredient that also has good nutritional benefits but has the same properties as flour as a raw material for making commercial brownies is Mocaf (Modified Cassava Flour) which is a processed product from cassava which is made by fermentation using lactic acid bacteria (BAL) so that it has Different characteristics of cassava flour or cassava. It aims at health and digestive effects. Some studies show the health benefits of modified cassava flour, among others, can improve heart health (Khan et al., 2018), reduce the risk of cancer (Narita, 2015), reduce the accumulation of food in the intestine to prevent constipation (Novarro et al., 2016), and inhibits the absorption of fat and cholesterol in the large intestine (Buddington et al, 2017). 
Based on the background that has been explained it shows that the use of mangrove fruit flour, kidney beans flour, and modified cassava flour has the potential as an alternative food to replace carbohydrates and has the nutritional benefits needed by the body. One type of use of food in mangroves is to make brownies. Based on the description above, this study was conducted to determine the nutritional quality of brownies by using raw materials of mangrove fruit flour, red bean flour, and modified cassava flour compared to wheat flour (control) as raw material for making commercial brownies so that people can gain knowledge for making brownies with value high nutrition.

\section{METHODS}

The studied used an experimental design using an experimental design that was a completely randomized design (crd). This researched was conducted in augustoctober 2019 in dumai. Sample testing was carried out at pspg (center for food and nutrition studies) gadjah mada university, yogyakarta

The main ingredient in this studied was the mangrove api-api (avicennia officinalis) flour pedada fruit flour (sonneratia caseolaris), which had been sorted and then dried or roasted and ground. Modified cassava flour was obtained from agricultural products in yogyakarta, red beans were obtained from the market then soaked, mashed, dried, ground and then sieved until it becomes red bean flour. wheat flour was obtained from traditional markets, rubbed ash, sugar, butter, vanilla, eggs, tbm, sp, cake softener. The equipment used was an oven, blender, baking pan, stove, mixer, container, knife, sifter, mold, etc.

All experiments and analyzes were carried out in three replications. Data obtained from various studied parameters were analyzed for variance/variance with $95 \%$ confidence intervals $(p<0.05)$. If the results of the analysis of variance were significantly different, then duncan's multiple range test was used to separate the averages (duncan, 1955). Then the data was processed using spss version 22 statistical software.

\section{Production of Mangrove Fruit Flour}

Mangrove fruit baked (not deformed and measuring 35-40 grams). Furthermore, mangrove fruit is washed and soaked with ash for 24 hours (replacing every 6 hours) to remove tannin then drained and reduced size to speed up the drying process. Drying with an oven at $70^{\circ} \mathrm{C}$ for 3 hours. The next step is drying in the sun for three days or the oven. And then milling and shifting using shifter with a size of 80 mesh.

\section{Production of Red Bean Fruit Flour}

Red bean flour is made from high-quality red beans weighing 25-50 grams each, not wrinkled, then soaked in cold water (room temperature) for 2 hours then drained, cut into 2 parts, dried in an oven at $70(70)-90^{\circ} \mathrm{C}$ ), roasted, or roasted to dry. To find out the red beans are ripe or not when roasted will pick a sound. Dried red beans are ground using a grinding machine, then filtered to get 80 mesh red bean flour.

\section{Brownies Preparation}

170 grams of butter is melted. Besides that, prepare a mixture of eggs with an amount of 6 eggs, SP 10 grams, Vanilla 10 grams, and 150 grams of sugar, stirring until blended using the oven. Furthermore, it is mixed with melted margarine. The next step was the addition of 676 grams of flour and mashed. After all the mixture is evenly mixed, fill it in the pan and bake at $170^{\circ} \mathrm{C}$ for 30 minutes.

\section{RESULTS AND DISCUSSIONS}

\section{Nutritional composition of chocolate brownies using several varieties of flours}

After the process of making brownies using different flour variations, then the samples were tested for nutritional composition including calorific values, crude fiber, and direct analysis. Based on the test results of calorie and crude fiber values, the data are presented in Table 1.

Table 1. Results of nutrient analysis of chocolate mangrove brownies

\begin{tabular}{cccc}
\hline No & Various of flour & Calory Content (ccal) & Crude fiber conten (\%) \\
\hline 1 & AF & $401,87 \pm 0,34^{\mathrm{a}}$ & $16,49 \pm 0,07^{\mathrm{b}}$ \\
2 & PF & $489,06 \pm 0,58^{\mathrm{b}}$ & $16,62 \pm 0,45^{\mathrm{bc}}$ \\
3 & MCF & $372,08 \pm 7,48^{\mathrm{c}}$ & $16,14 \pm 0,05^{\mathrm{b}}$ \\
4 & RBF & $353,80 \pm 1,80^{\mathrm{d}}$ & $14,67 \pm 0,26^{\mathrm{a}}$ \\
5 & WF & $679,77 \pm 6,91^{\mathrm{e}}$ & $13,53 \pm 0,23^{\mathrm{d}}$ \\
\hline
\end{tabular}

Note: AF: Api-Api fruit flour, PF: Pedada fruit flour, MCF: Mocaf, RBF: Red Beans Flour WF: Wheat flour

The Different Superscript notations show significant differences at the test level $\alpha=5 \%$.

Based on Table 1 it can be concluded that the mangrove flour brownies (A, B), mocaf (C) and red bean flour (D) are higher in fiber and lower in calories than commercial brownies made from wheat flour as control (E). Brownies that have the highest fiber content are brownies derived from mangroves (A and B) followed by mocaf brownies and kidney beans. Brownies derived from pedada fruit flour had the highest levels of crude fiber from the use of Api-api (Avicennia officinalis) fruit flour, mocaf flour, red bean flour, and wheat flour (Control), this is due to the fiber content of the mangrove fruit pedada used as raw material already has a high fiber content compared to other raw materials. According to Jariyah (2019), mangrove fruit pedada has a high fiber component that is equal to $9.80 \%$ 
soluble dietary fiber and $53.90 \%$ of insoluble dietary fiber. The crude fiber content in the mangrove fruit flour shows the highest value, this is confirmed by the statement from Jariyah et al., (2016) Pedada fruit flour made from Pedada fruit (Sonneratia caseolaris). This flour has a high fiber content $(63.70 \%)$ and has the potential to be used as a functional food.

Fiber is very beneficial for the digestive system of the body because it can facilitate bowel movements, therefore many food sources with high fiber are used as alternative food. According to Gropper and Smith (2013), Fiber is part of carbohydrates that cannot be digested by digestive enzymes. The crude fiber in red bean and mocaf brownies is quite high, this is due to the high fiber content of red bean raw material compared to wheat flour as a control, in addition to the mocaf flour brownie fiber content is also higher than wheat flour.
Crude fiber Brownies made from mangrove fruit flour, mocaf flour, and red bean flour is higher than control brownies made from wheat flour (Table 1). Brownies made from mocaf flour $16.14 \%$. The high content of mocaf flour brownie fiber is caused by the raw material that is mocaf flour also has high fiber. According to Salim (2011), the higher the ratio of mocaf flour to wheat flour, the higher the level of crude fiber produced. According to Prayitno (2018), the crude fiber content in the mocaf is around $1.9-3.4 \%$, the cassava flour mocaf brownies fiber is 2.27 $6.93 \%$. The amount of crude fiber increases with increasing mocaf flour concentration. The increase in crude fiber is also caused by an increase in mocaf flour containing fiber. In addition to mocaf flour, brownies made from red bean flour also contain high fiber content. According to Dewi et al., (2015), kidney beans (Phaseolus vulgaris L.) are one type of legume (Leguminoceae) which has a high starch and fiber content.

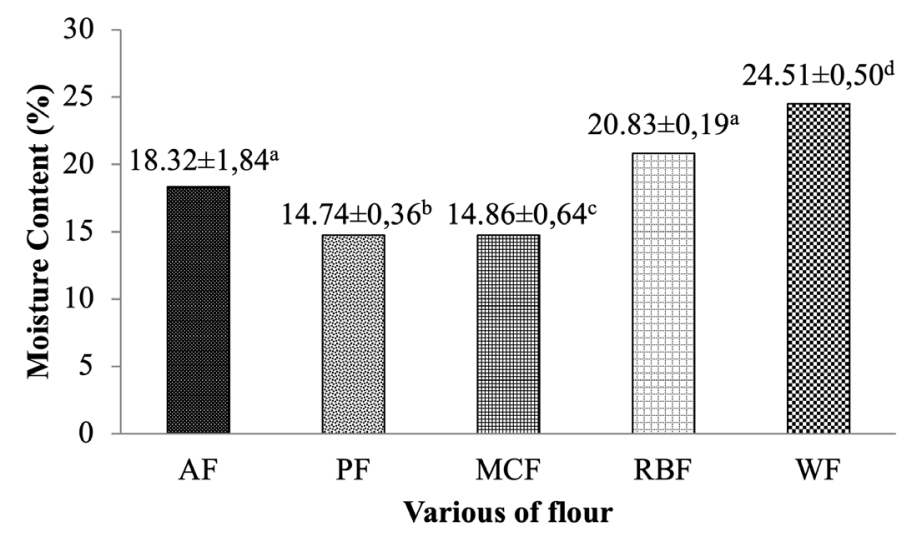

Figure 1. The moisture content of chocolate brownies in various flour

Note: AF: Api-Api fruit flour, PF: Pedada fruit flour, MCF: Mocaf, RBF: Red Beans Flour WF: Wheat flour

The Different Superscript notations show significant differences at the test level $\alpha=5 \%$.

\section{Proximate composition of chocolate brownies with various flour}

The average moisture content in brownies is $14.74-24.61 \%$ with the highest water content values obtained in control brownies which are made from flour (E), followed by brownies made from red bean flour (D). While the low water content is found in brownies with the basic ingredients of mangrove fruit flour pedada (B) and mocaf flour (C). The content of water content in the material is influenced by several factors such as the initial water content of the raw material, the method of cooking brownies, the amount of water that evaporates during the brownies roasting process, the amount of starch and fiber contained in the brownies, and the length of the brownie baking. The moisture content of pedada fruit flour brownies is lower (14.74\%) compared to wheat flour brownies $(14.95 \%)$. The moisture content of the material is also influenced by the initial water content of the raw material. Brownies that use raw materials of wheat flour and red bean flour have higher water content, due to their lower starch content compared to mangrove fruit flour (PF or AF) and MCF This is because the amylose and amylopectin content in starch has the ability to bind water so that the higher the starch content, the higher the water holding capacity during the preserve process. According to Rahmah et al., (2017), water absorption is influenced by amylose content in starch. Amylose has a straight structure and contains a lot of hydroxyl groups making it easier to bind and release water. The length of time for roasting is due to water evaporation and fat melting (Setyaningsih et al., 2019). According to Sunarsih (2012), that the water content of wheat flour $(12 \%)$ is higher than mocaf flour (6.9), this also makes brownies produced from wheat flour have a higher water content when compared to the water content of brown brownies derived from mocaf flour.

The results of the analysis of variance showed that fat content was not significantly different $(p>0.05)$ to the variation of flour used in making chocolate brownies. Brownies' fat content is in the range of $21.7-26.79 \%$. Fat content in brownies is influenced by several factors, including the initial fat content of various raw materials used, the cooking process, the use of roasting temperatures, and the duration of roasting. The longer roasting duration and the higher temperature cause the process of melting the fat content of the material so that some of the fat will meltdown with the material and a small portion is carried 


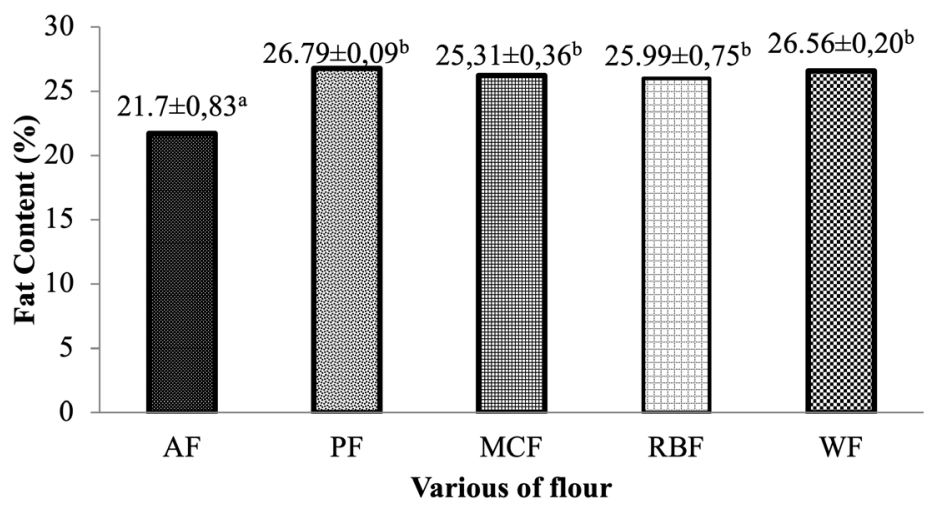

Figure 2. The fat content of chocolate brownies in various flour

\author{
Note: AF: Api-Api fruit flour, PF: Pedada fruit flour, MCF: Mocaf, RBF: Red Beans Flour \\ WF: Wheat flour \\ The Different Superscript notations show significant differences at the test level $\alpha=5 \%$.
}

with the water vapor and air in the oven during the roasting process. The results of this study indicate that the fat content of mangrove flour brownies is lower than the control (E). The results of this study are in line with previous studies which stated the fat content of mangrove flour brownies was lower at $11.94 \%$ compared to wheat flour brownies at $30.42 \%$. In mangrove flour, there is a fat content of $1.08 \%$ (Hamsah, 2013) and wheat flour 1.5-2\% (Aufari, 2013).
According to Pertiwi et al., (2018), the more substitution of pedada flour, the fat content will increase even in small amounts. According to research by Fatimah and Rahayu (2016), the substitution of pedada fruit flour (Sonneratia caseolaris) in making brownies with low-fat content. According to Purwanita (2013), the fat content of tapioca flour was only $0.5 \%$, whereas in the study by Hamsah (2013), the fat content of pedada fruit flour was $1.19 \%$.

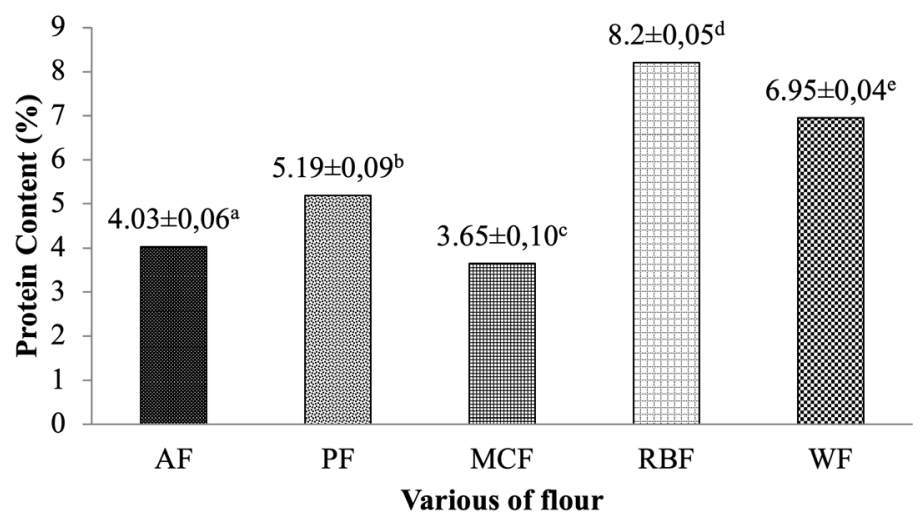

Figure 3. The protein content of chocolate brownies in various flour

Note: AF: Api-Api fruit flour, PF: Pedada fruit flour, MCF: Mocaf, RBF: Red Beans Flour WF: Wheat flour

The Different Superscript notations show significant differences at the test level $\alpha=5 \%$.

The protein content is in the range of an average value of $3.65-8.2 \%$ with the highest protein content found in brownie flour and red bean flour. The protein content of brownies is influenced by several factors including the initial protein content of the raw material, temperature and roasting time, cooking methods, chemical reactions that occur in amino acids with other chemical content in materials such as carbohydrates (the cause of the Maillard reaction), amino acid reactions with reducing sugars in materials with high carbohydrate content, the reaction of protein hydration and denaturation results in a decrease in protein content in the ingredients. The longer the roasting process and the higher the temperature used, the protein content contained in the food will also decrease.
The protein content in brownies made from mocaf showed the lowest value, due to its manufacturing process that removes gluten (protein in flour) which functions to develop food. Gluten is a part of wheat flour protein. Wheat flour has a function as a dough framework that occurs due to the presence of wheat protein (gliadin and glutenin) and starch (Imzalfida, 2016: 2). Besides, the process of making mocaf is through the fermentation process so that complex compounds such as proteins will break down into smaller compounds such as amino acids and gases where amino acids can react with other chemical compounds contained in brownies. According to Wulandari and Mustofa (2010), the advantage of Mocaf flour compared to other flour in food preparations is that it is easy to be fortified with other flour because of low protein content so that it can be 
strengthened with other vegetable protein sources.

The highest protein content was found in brownies made from red bean flour, this is because the initial protein content of the raw material is already high. High levels of protein in red bean brownies are associated with high levels of water in red bean brownies. The higher the protein content, the higher the water content, this is confirmed by research from Asfi et al., (2017) the more addition of red bean flour, the higher the protein content. Andarwulan et al., (2011) explained that The ability of proteins to bind water is caused by the presence of hydrophilic groups. The presence of water absorption is due to carboxyl groups in proteins. Water will be absorbed by amino acids by hydrogen bond. The higher protein contained in red bean flour, the more water is absorbed (Andarwulan et al., 2011).
Research by Manonmani et al., (2014) showed that the higher the percentage of red bean flour used, the higher the protein content.

Protein content in mangrove fruit brownies is in the range of $4.03-5.19 \%$ (Figure no 3). Protein content contained in mangrove fruit brownies is influenced by the initial content of raw materials. The higher of protein content from the raw material is same higher the protein content of the brownies produced. Related to the substitution of pedada fruit flour in brownies stated by Fatimah and Rahayu (2016), substitution of pedada fruit flour (Sonneratia caseolaris) was able to increase protein content in brownies products by $6.73 \%$. Crude protein in fish nugget products increases with the addition of mangrove fruit flour (Amalia et al., 2016)

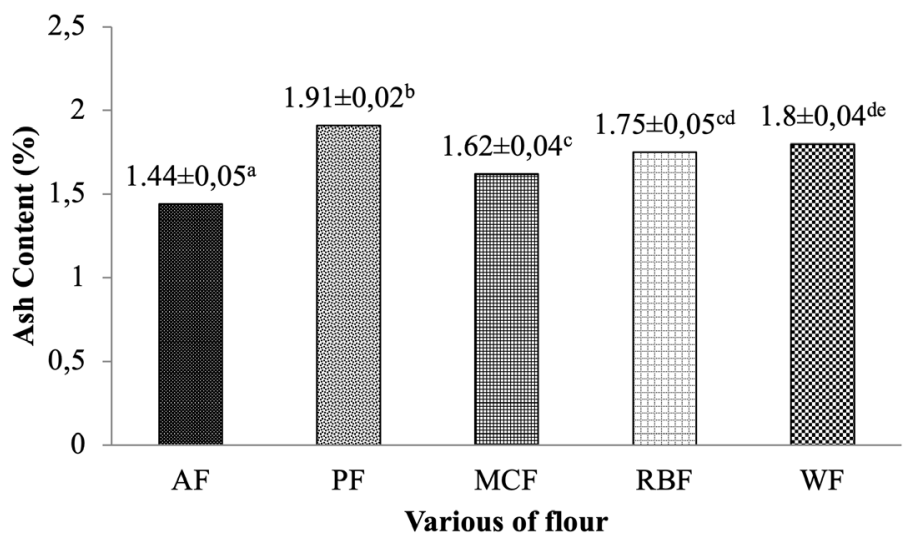

Figure 4. The fat content of chocolate brownies in various flour

Note: AF: Api-Api fruit flour, PF: Pedada fruit flour, MCF: Mocaf, RBF: Red Beans Flour WF: Wheat flour

The Different Superscript notations show significant differences at the test level $\alpha=5 \%$.

Ash content is in the range of $1.44-1.91 \%$ (Figure No 4). Ash content value related to mineral content contained in brownies. Ash content is an inorganic residue from the ashes process and usually, the components contained in inorganic compounds are potassium, calcium, sodium, iron, magnesium, and manganese. The ash content of Pedada mangrove flour (B) is higher than wheat flour $(\mathrm{E})$. This is in line with the research by Fatimah (2016), that ash content of pedada fruit flour is higher than wheat flour.

Ash content in mocaf flour $(\mathrm{C})$ is also lower than wheat flour (E), this is because the raw material for mocaf flour has a smaller ash content than wheat flour. According to Djalal et al., (2011), the composition of mocaf ash content is in the range of 0.2 percent. Meanwhile, according to Widasari (2014), one of the advantages of mocaf flour compared to wheat flour is that mocaf has a lower ash content which is around 0.4 percent, while flour is around 1.3 percent.

The carbohydrate content is in the range of an average value of $43.40-54.64 \%$ with the highest carbohydrate content found in mangrove and wheat flour brownies (control) while the lowest carbohydrate content is found in red bean flour brownies and mocaf flour (Figure 5). Carbohydrates are the main source of nutrients in the composition of the menu of daily food in the most Indonesian people. In general, carbohydrate content ranges from $60-70 \%$ of total energy consumption (Dewi, 2018). According to Rahmah et al., (2017). The carbohydrates have a major role in the body that is as an energy producer. The carbohydrates also play an important role in determining the characteristics of a food, besides that some carbohydrates produce dietary fiber which is useful for digestion. Some research results show that mangrove flour has a carbohydrate content of $82,29 \%$ (Hamsah, 2013) and wheat flour 77.30\% (Dewi et al, 2013: 4). Wheat flour has 60-68\% starch content (Salim, 2011: 13), amylose content $64.23 \%$ and amylopectin $8.11 \%$ (Imzalfida, 2016: 55). Utilization of mangrove fruit flour (Sonneratia caseolaris) is based on high carbohydrate content in bogem fruit flour of 82.29\% (Hamsah, 2013) and wheat flour 77.3\% (Dewi et al, 2013: 4). The major of constituents in carbohydrates is starch (amylose and amylopectin). It is expected that the role of mangrove fruit flour (Sonneratia caseolaris) starch to replace the role of starch together with gluten from flour can (Dewi, 2015)

According to Normasari (2010), these microbes also produce enzymes that hydrolyze starch to sugar and then convert it to organic acids, especially lactic acid. Mocaf is modified cassava flour through the process of fermentation 


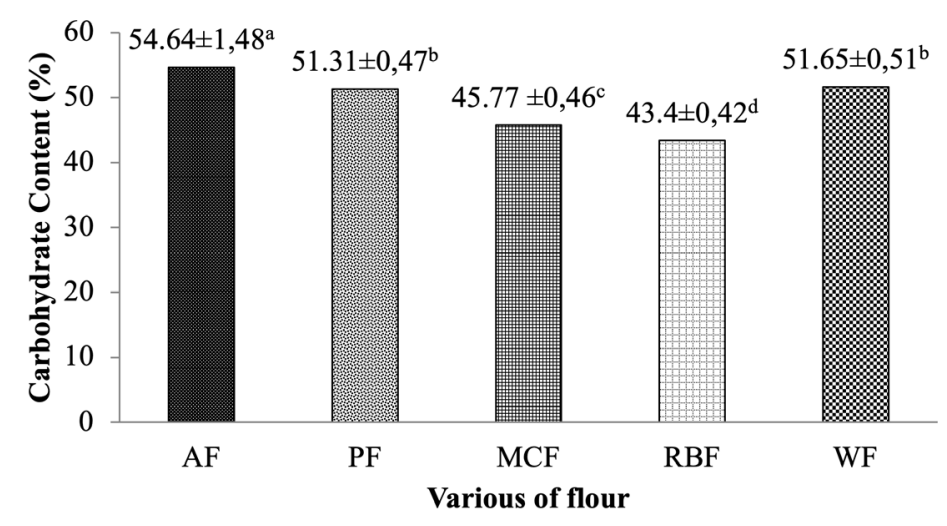

Figure 5. The carbohydrate content of chocolate brownies in various flour

Note: AF: Api-Api fruit flour, PF: Pedada fruit flour, MCF: Mocaf, RBF: Red Beans Flour WF: Wheat flour (Control)

The Different Superscript notations show significant differences at the test level $\alpha=5 \%$.

by lactic acid bacteria, so that it changes the functional properties of and can be used to replace wheat flour in the manufacture of wheat-based food products. Several studies have examined that mocaf can replace wheat flour technically up to 100 percent as raw material in the manufacture of brownies, wet cakes and pastries (Ruriani et al., 2013).
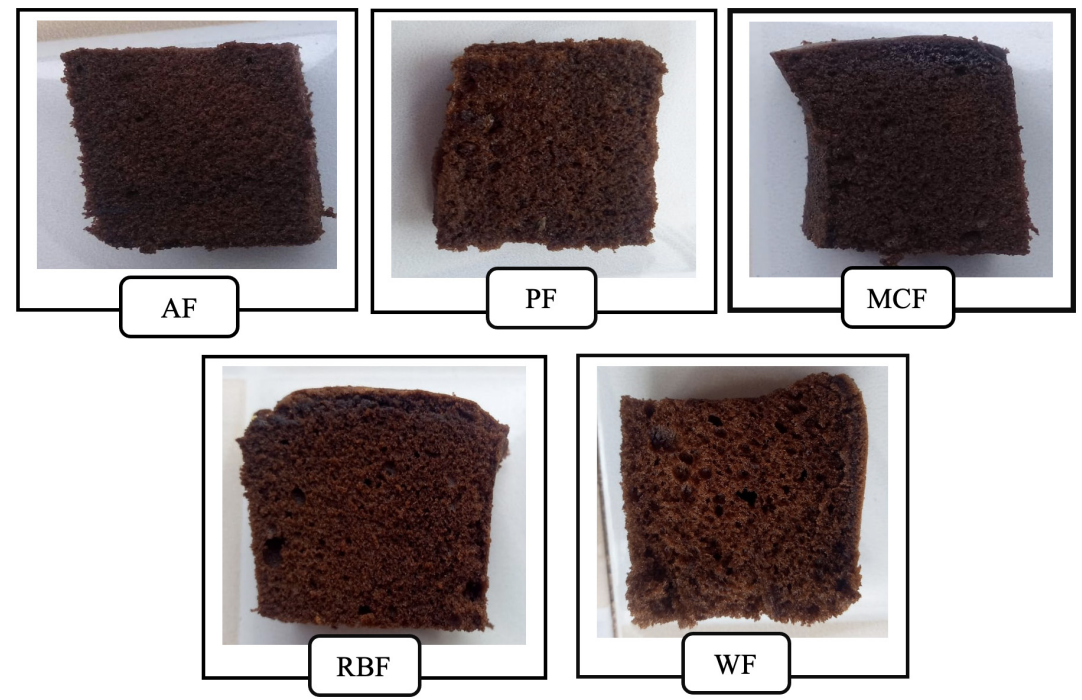

Figure 6. The phorous appearance of chocolate brownies in various flour

Note: AF: Api-Api fruit flour, PF: Pedada fruit flour, MCF: Mocaf, RBF: Red Beans Flour WF: Wheat flour (Control)

The Different Superscript notations show significant differences at the test level $\alpha=5 \%$.

\section{Appearance and pore structure of Chocolate Brownies}

Based on Figure 6, The picture of the results of research on making brownies from different flour shows that the fire fruit flour brownies (A) and pedada fruit (B) appear to have tight pores, this is because mangrove flour has a smaller amount of protein if compared to chocolate brownies derived from wheat flour (E) (based on the data in Figure 6 , the pores formed during roasting brown brownies are the effects of a protein called gluten, which is a protein that is not soluble in water, has elastic properties like rubber and is a framework of chocolate brownies so that in the manufacture of chocolate brownies the presence of gluten is an absolute requirement that must be contained by flour to bring up pores and cavities, form the texture and development of the dough. The best texture and pores are showed by mocaf flour and red bean flour because it has sofa softer texture and smaller pores, but pores produced from mangrove flour also has a small pore but has a texture that is not soft and uneven because there is a sensation of mangrove flour grain. According to Dewi's research (2016), the pores expected from the organoleptic brownie test results are small pores and large amounts with roasting as cooking method. Wheat is a network and framework of brownies as a result of gluten formation. The protein contained in wheat flour that is not soluble in water will absorb/absorb water and form a glute which will hold the gas produced from the influence of yeast. 


\section{CONCLUSIONS}

Based on the research results, brownies are made from various variations of flour show that in terms of nutrition and nutrients that, Brownies made from Pedada Mangrove flour (Sonneratia caseolaris) is the best food source of energy sources that are high in fiber and lower in calories.

\section{REFERENCES}

A'IN C, SURYANTI, SULARDIONO, B.(2017). KANDUNGAN GIZI PADA PRODUK OLAHAN MANGROVE (KRUMANG, BOMANG, DAN SIMANG) PRODUKSI KELOMPOK TANI "NGUDI MAKARYO" ". JURNAL INFO VOLUME 19, NOMOR 1.

Asfi,WM., Harun,N.,Zalfiatri,Y.(2017). Pemanfaatan tepung kacang merah dan pati sagu pada pembuatan crackers. JOM Faperta UR Vol. 4 No. 1 Februari 2017

Andarwulan,N., F. Kusnandar dan D. Herawati.(2011). Analisis Pangan. PT. Dian Rakyat. Jakarta.

Astawan, M., Febrinda, A.E.(2010). Potensi Dedak dan Bekatul Beras Sebagai Ingredient Pangan dan Produk Pangan Fungsional. Vol. 19 No. 1 Maret 2010

Damayanti, DA, Wahyuni,W, Wena,M.(2014). Kajian kadar serat, kalsium, protein, dan sifat organoleptik chiffon cake berbahan mocaf sebagai alternatif pengganti terigu. Jurnal Teknologi dan kejuruan, vol. 37, no. 1, pebruari 2014:73-82

Dewi,S., Trisnawati,C.Y, Sutedja, A.M. (2015).Pengaruh substitusi terigu dengan tepung kacang merah pregelatinisasi terhadap sifat fisikokimia dan organoleptik cookies. Journal of Food Technology and Nutrition Vol 14 (2): 67-71, 2015

Dewi, D.P. (2018). Substitusi tepung daun kelor (Moringa oleifera L.) pada cookies terhadap sifat fisik, sifat organoleptik, kadar proksimat, dan kadar Fe. Jurnal Ilmu Gizi Indonesia Vol 01, No.02, 104-112

Dhingra D, Michael M, Rajput H, Patil RT.(2012) Dietary fibrein foods: a review. Journal of food science and technology. 2012; 49(3):255-66. doi: 10.1007/s13197-011-0365-5

Gropper SS, Smith JL. (2013). Advanced nutrition and human metabolism 6th ed. USA: Wardsworth Cengage Learning.

Fatimah,S.(2016). Pengaruh Substitusi Tepung Buah Bogem (Sonneratia caseolaris) dan Teknik Pemasakan terhadap Sifat Organoleptik Brownies. e-journal Boga, Volume 5, No. 1, Edisi Yudisium Periode Februari 2016, Hal 201 - 210. https:/jurnalmahasiswa.unesa.ac.id/ index.php/jurnal-tata-boga/article/view/14098/12843

Jariyah, J.,Widjanarko,S.B.,Yunianta,Estiasih,T.(2016). Quality evaluation of Wheat-Pedada Fruit Flour (PFF) biscuit with different emulsifiers, 9 : 518-524. doi: 10.1016/j.aaspro.2016.02.171

Jariyah,J.,Widjanarko,S.B.,Yunianta.,Estiasih,T.,Sopade,P.A. Pasting properties mixtures of mangrove fruit flour (Sonneratia caseolaris) and starches. International Food Research Journal 21(6): 2161-2167 (2014)

Jariyah,J.(2019). Glycemic Index of Snack Bar from Pedada Fruit Flours (Sonneratia caseolaris) and Legumes Flour. Atlantis Highlights in Engineering (AHE), volume 1

Khamidah,A, Alami,EN.(2011). Pembuatan brownies kukus kasava (nonterigu) dengan substitusi talas belitung dan tomat. Prosiding Seminar Hasil Penelitian Tanaman Aneka Kacang dan Umbi. Balai Pengkajian Teknologi Pertanian Jawa Timur

Ligarnasari,IP ., Anam, C., Sanjaya, AP. (2017). Physical, chemical and sensory properties of brownies substituted with sweet potato flour (Ipomoea batatas L.) with addition of black cumin oil (Nigella sativa L.) International Symposium on Food and Agro-biodiversity (ISFA) 2017. https://iopscience.iop.org/article/10.1088/1755-1315/102/1/012084

Manonmani,D.,Bhol,S.,Bosco,S.J.D.(2014). Effect of Red Kidney Bean (Phaseolus vulgaris L.) Flour on Bread Quality.1;1-6. http://dx.doi. org/10.4236/oalib.1100366

Normasari, R.Y.(2010). Kajian penggunaan tepung mocaf (modified cassava flour) sebagai subtitusi terigu yang difortifikasi dengan tepung kacang hijau dan prediksi umur simpan cookies. [Skripsi]

Nuryani.(2013). Potensi subtitusi beras putih dengan beras merah sebagai makanan pokok untuk perlindungan diabetes melitus. Media Gizi Masyarakat Indonesia, Vol. 3. No. 3, Desember 2013, hlm. 157-168

Okoye,J.I., Nkwocha, A.C,Agbo,A.O.(2008). Chemical composition and functional properties of kidney bean/ wheat flour blends. 2: 27-32

Olaofe, O., J.A. Famurewa and A.O. Ekuagbere, (2010). Chemical and functional properties of kidney bean seed (Phaseolus vulgaris L.) flour. Int. J. Chem. Sci., 3: 51-69.

Pentury,MH.(2016). Analysis of Physical and Chemical of Starch Lindur (Bruguiera Gymnorrhiza), Pedada (Sonneratia Casiolaris) and ApiApi (Avicennia Marina). Journal of Environment and Ecology ISSN 2157-6092 2016, Vol. 7, No. 2

Pertiwi, M., Herpandi., Nopianti, R.(2018). Karakteristik Fisiko-Kimia dan Sensori Bakso Ikan Parang-parang (Chirocentrus dorab) dengan Substitusi Tepung Buah Pedada (Sonneratia caseolaris). 7(1) : 1-13

Prayitno, S.A., Tjiptaningdyah,R.,Hartati,F.K.(2018). the chemistry and organoleptic brownies steamed from the proportion of mocaf (modified cassava flour) and wheat flour, 10(1):2018. https://doi. org/10.17969/jtipi.v10i1.10162

Purwonegoro, PI, Sulistiyati, TD. (2019). Substitution of Eucheuma cottonii Seaweed Flour Against Acceptability and Hardness of Steamed Brownies. International Journal of Scientific and Research Publications, Volume 9, Issue 6, June 2019 102. ISSN 2250-3153

Rahmah, A.,Hamzah, F.,Rahmayuni.(2017). Penggunaan tepung komposit terigu, pati sagu, dan tepung jagung dalam pembuatan roti tawar. Jom FAPERTA Vol. 4 No. 1

Reni, N, Budi, S. (2018). Pengembangan produk brownies dengan substitusi tepung oncom hitam dan sorgum untuk balita gizi kurang. Institut Pertanian Bogor : Bogor [Skripsi]

Ruriani, E.,Nafi,A., Yulianti, L.D, Subagio, A. (2013). Potency Identification of MOCAF (Modified Cassava Flour) as Technical Substitution of Wheat Flour in Small and Medium Enterprises in East Java.

Setyaningsih, D.N., Fathonah,S.,Putri, R.D.A, Auda,A.K, Solekah,N. (2019). The influence of baking duration on the sensory quality and the nutrient content of mung bean biscuits. Food Research 3 (6) : 777 - 782 (December 2019)

Sunarsih, S. (2012). Memanfaatkan Singkong Menjadi MOCAF untuk Pemberdayaan Masyarakat Sumberejo. Sukoharjo: LPPM Univet Bantara Sukoharjo.

Uruakpa,FO, Fleischer,AM. (2016). Sensory and Nutritional Attributes of Black Bean Brownies. American Journal of Food Science and Nutrition 2016; 3(3): 27-36

Wahyuni,S, Holilah,Asranudin, Noviyanti.(2018). Estimation of shelf life of wikau maombo brownies cake using Accelerated Shelf Life Testing (ASLT) method with Arrhenius model. IOP Conf. Series: Earth and Environmental Science 122 (2018) 012082

Wulandari,YW.,Mustofa,A.(2010). karakteristik kimiawi tepung mocaf dengan variasi fermentasi spontan menggunakan youghurt sebagai starter cultur.(1) : 18-22

Widasari, M.(2014). Pengaruh proporsi terigu - mocaf (modified cassava flour) dan penambahan tepung formula tempe terhadap hasil jadi flake. e-journal Boga, Vol (3), No. 3 Oktober 2014, hal 222-228 